\title{
Liveable Open Public Space - From Flaneur to Cyborg
}

\author{
Aleksandra Djukic $^{1(\bowtie)}\left(\mathbb{D}\right.$, Thanos Vlastos $^{2}$, and Viera Joklova ${ }^{3}$ \\ ${ }^{1}$ Faculty of Architecture, University of Belgrade, Belgrade, Serbia \\ adjukic@afrodita.rcub.bg.ac.rs \\ 2 Department of Geography and Regional Planning, \\ National Technical University, Athens, Greece \\ vlastos@survey.ntua.gr \\ 3 Slovak University of Technology, Bratislava, Slovakia \\ viera.joklova@stuba.sk
}

\begin{abstract}
Open public spaces have always been key elements of the city. Now they are also crucial for mixed reality. It is the main carrier of urban life, place for socialization, where users rest, have fun and talk. Moreover, "Seeing others and being seen" is a condition of socialization. Intensity of life in public spaces provides qualities like safety, comfort and attractiveness. Furthermore, open public spaces represent a spatial framework for meetings and multileveled interactions, and should include virtual flows, stimulating merging of physical and digital reality. Aim of the chapter is to present a critical analysis of public open spaces, aspects of their social role and liveability. It will also suggest how new technologies, in a mixed reality world, may enhance design approaches and upgrade the relationship between a user and his surroundings. New technologies are necessary for obtaining physical/digital spaces, becoming playable and liveable which will encourage walking, cycling, standing and interacting. Hence, they will attract more citizens and visitors, assure a healthy environment, quality of life and sociability. Public space, acting as an open book of the history of the city and of its future, should play a new role, being a place of reference for the flaneur/cyborg citizen personal and social life. The key result is a framework for understanding the particular importance of cyberparks in contemporary urban life in order to better adapt technologies in the modern urban life needs.
\end{abstract}

Keywords: Liveability $\cdot$ Walkability $\cdot$ Mixed reality $\cdot$ Quality of life $\cdot$ Cyborg

\section{Introduction}

Real reality, Amplified reality, Augmented reality, Mediated reality, Augmented virtuality, Virtualized reality, Virtuality. These are versions of a real world which is enriched by the accelerating influence of a new digital world. A new reality, or meta-reality, which appears to be both complex and attractive, is created, particularly for young people. Digital world is penetrating almost in every aspect of the 'real' life. The result is a mixed reality which could make our everyday life pleasant, educating and inspiring for addressing consciously and responsibly the problems of the planet. It will also provide 
conditions for helping us to communicate, to meet and to coordinate our coexistence. Mixed reality will bring future sustainable city closer to its citizens. They will no more act as passive spectators but rather as active players and participants for the city's development. Mixed reality will contribute to the implementation of a user centred planning for cities belonging to everybody, with no exclusions. They will be liveable, accessible and fair, true public cities with fewer inequalities and socially cohesive.

Public spaces are the right environment to enjoy with all the senses. Images, sounds, colours and smells are qualities that can be felt because the attention doesn't focus on how to avoid cars but freely turns to what really touch the heart of the user. They offer a richness of experience, possibilities for action and leisure (Stevens 2007). Furthermore, open public spaces are places of collective presence, communication, gatherings and celebrations, or political rallies. Lefebvre's pointed that "the city is the imprint of the society in space", by which he perceives space as a product of thought and action, but as well as an instrument of control and expression of power (Lefebvre 1991). Everyday routine takes a break in public spaces. They are places of rest, places where work stops, where you can chat without an agenda, where kisses and hugs deserve a place. Public spaces are places of pauses where the mind and body relax. What differentiates open and closed public spaces is that visitors to the former are there without a specific reason, they are not oriented towards a certain activity, they simply relax, look around at passers-by. In open public spaces, one can find again his/her freedom, which the function and aesthetics of closed spaces has taken away from him/her. It is a fact that, since antiquity and until today, architecture tried to integrate man from the open to the closed space, in order to discipline and control his thoughts and emotions. Naturally, modern architecture is today bare of ideology and symbolism, as is our era, its only aim is functionalism and to impress. The result is in stereotyped industrialised products and places, without an identity.

Open public spaces are only attractive for users if there is a certain concentration of people. When an osmosis between open spaces and the city occurs - it is an osmosis of the human presence in the streets with the human presence in public spaces. This way, public spaces being connected with the movement of pedestrians and cyclists in the streets, give them the opportunity for some pauses, meetings and mutual experiences with their visitors. In the second half of the $19^{\text {th }}$ century, trade gained great importance in the cities again. This time it becomes part of the fun and lifestyle of the higher strata of civil society. Open public spaces, especially those with shopping activities, became the most important places in the city for leisure time. The open public spaces were reviving and becoming places of gathering. At the same time, at the beginning of the $20^{\text {th }}$ century, large shopping centres, partially or completely covered open public spaces, were developed mainly in Western European countries, providing comfort from weather conditions (such as arcades in Paris in the late $19^{\text {th }}$ century and many department stores in the cities of Europe). The appearance of department stores was preceded by exhibitions (Gandl 2007). The protected areas of department stores become a prototype for the middle class to purchase and spend free time. In contrast to that, spending time on the street, connected with the cultural urban phenomenon, the flâneur, who is an unconscious youth, artist or writer, with bohemian behaviour, that conducts days in cafes and on the street with a cynical view of the world around him, was first proposed by Charles Baudelaire in 1863. In the middle of the $19^{\text {th }}$ century, 
spending time or gathering on the street was incriminated and was considered immoral for women. "The presence of unprotected women on the streets represents a threat to male power and male weakness. Despite the fact that men in power did everything to limit the movement of women in cities, it is impossible to completely remove them from open public places. Women continue to gather in the city centre and within factories" (Watson and Gibson 1995: 61).

Unlike open-air public space, shopping at a department store has been considered acceptable. Department stores could fulfil the most of their wishes. They were, in fact, closed worlds - small towns. They influenced the closure of small shops and contributed to the formation of a new zone of the city, a "pleasure zone", as the customer was characterized as someone who is looking for satisfaction, material goods, performances and public life (Rappaport 2000).

In the first half of $20^{\text {th }}$ century, after the proclamation of the Athens Charter of 1933, the avant-garde of architecture and urbanism, led by Le Corbusier, Gropius and Jacobs advocated for a radical transformation of the city. They insisted on a transformation with a thesis that "chaotic and disordered cities with many social problems should be rationally rearranged and clearly organized, with a dominant influence of technology" (Bridge and Watson 2002). The strongest influence on these attitudes had Le Corbusier, who insisted on introducing the legibility and transparency in urban areas. Implementation of these values would be carried out by uniform zoning (zoning plan). Emphasizing the importance of urban open space as a "large central open space that allows spectacular order and vitality" (Forty 2004: 140), the social value of the street is negated, as well as its historical and cultural value, significance and architecture. Followers of modern architecture were advocated for abolishing of the social function of the streets. Furthermore, they were trying to invent and create such a form that would be fully able to replace the street with a new infrastructure built for cars and not for the human presence. Certain architects and theorists of architecture and urban planning did not agree with such theses. Christopher Alexander was an opponent of this "street theory", believing that the streets should be shaped and arranged in such a way to keep the passers-in as long as possible. Jane Jacobs emphasized the central role of the streets (especially commercial) in establishing the urban life of the community, arguing that multifunctionality is supported by the mechanism of "self-regulation of street life" and that thus increases the level of security (Jacobs 1995). Mies van der Rohe, as a supporter of functionalism in architecture, observed that the social values and construction technology should be placed before form and that all structures and facilities should be subordinate to their function and purpose of (Forty 2004: 165).

Theorists-rationalists, Lash and Friedman, believed that the streets should have an exclusively traffic function and serve to the fastest way of transport of people and goods from one point to the other (Lash and Friedmann 1992). These thoughts were also the imperatives of modernist planning and consumer capitalism, who sought to transform the symbolic shopping streets into functional spaces that maximize consumption and facilitate transit (Fyfe 1998). The ideology of fascism has supported ideas (called neo-classical) about straight and wide avenues that would provide a fast flow of traffic and a sufficient amount of sunshine and ventilation. They should be designed in accordance with the principles of public morality dictated by the state. One of the most famous projects realized during the fascist period is the reconstruction of Via del Mare 
in Rome (Kostof 1973). These principles were implemented also in Brasilia in 1960, where only high-speed avenues were constructed, as well as cul-de-sac residential streets, while the social dimension of the streets was completely neglected. Walking was undervalued in the same way that the historical city was scorned worldwide. The objection against the latter didn't concern its architecture but its public character. The construction of many shopping centres in the prefixes of US cities, and also in West European cities was supposed to replace trade at main or local streets. Practically, shopping malls have become surrogates of the shopping streets of the city centre (Crawford 1992).

In 1980's open public spaces were in a focus of architects and urban designers again. The urban concepts of car free cities and New Urbanism have been launched and influenced the concepts of planning and designing of open public spaces. The urban design has been oriented towards the users' needs trying to achieve "more collective and more responsible city". Walking and cycling have been again observed as an 'active' type of transport, as they obviously serve the important values of quality of life. After the signing of the Alborg (1994), most European cities, signatories of this treaty, plead for upgrading sustainable mobility and favouring pedestrian and bicycle movement, with the goal to promote sustainable urban development. This is additionally based on the launching of numerous initiatives and activities throughout Europe which promote pedestrian movement.

\section{Cultural Aspects of Open Public Spaces}

Cultural aspects of open public spaces are result of the overlapping of morphological and functional characteristics. These characteristics create the identity of the open space. Cultural context as the main factor of identity is an unavoidable part of collective memory with its incorporated signs (Djukic 2011).

\subsection{Morphological Framework of Open Public Spaces}

The physical character of space is the product of a physical form, or as Kropf says, "The most important part of our perception of the character of space is the physical fabric of the place" (Kropf 1996; Hall 1996). He adds that the previous thesis is an axiom of urban design, urban morphology and landscape architecture, and that, in essence, this concept has now been rehabilitated as a valid planning method. Cullen (1961), while exploring the psychological and emotional aspects of the experience of urban ambiance, also pointed to the importance of the perception of morphological characteristics of the city by the user, while passing along the streets and paths. As users of open spaces, we mostly observe objects that define them as part of a wider field of view. Most often, we rarely enter these objects, but after leaving this scene, even if we move fast, along our movement, we can easily bring judgment about the character and quality of that space (Bentley et al. 1985).

In a study that examined the positive effects of urban design (done by the CABE Commission for Architecture and Built Environment and DETR 2001), in the section dealing with urban design, the quality of open public space is measured by the number 
of users and their flow through the selected space. It is concluded that the number of users is directly dependent on the physical characteristics of the subject area (urban structure, the relationship between the block, the street and the plot, the intensity of the activity, the type of objects, the facade, the details and materialization, the street front and the streetscape/landscape).

\subsection{Functionality}

Open public spaces are used by different protagonists, often of subtle values and views. However, managing these spaces is extremely complex and produces a series of problems (Sennett 1974). These problems are mostly related to the conflicts between activities and their intensity, as well as the regime of functioning (Djukic 2011). Open public space has the function of moving, gathering and retaining users (pedestrians, vehicles). On the one hand, the content of the activity indirectly influences the character of the place, and on the other hand the formed physical structure determines the functions and defines the contents in objects that are built along its boundaries (Djukic 2011). The current physical structure determines the future physical structure that will take its place in the future. In the book The Death and Life of Great American Cities, (Jacobs 1961), the author deals with the phenomenon of urban life and highlights the significance of the streets and open public spaces for the livelihoods of cities, comparing them with the heart of the city. She also noted that the key role of open public space is in accepting pedestrians and in their animation (both the local population and the visitor). The basis of vital life in the street is the diversity of both physical forms and functions and activities in it. Furthermore, the quality of the physical structure of the city refers to its connection with functions (primarily in the ground), the dimension of the blocks (primarily the shredding), the position of the front door (direct access to ground floor facilities), possibility of choosing the path for pedestrian traffic, etc. (Djukic 2011).

The concept of Jane Jacobs was supported by the group of professors from Bartlett School of Architecture and Planning in 70's. One of the results of this research was the space syntax method (B. Hillier and J. Hanson) which was focused on the social and physical aspect of open urban spaces. Space syntax uses quantitative methods (counting of pedestrians and vehicles) to get connections between the built space, the functions and liveability of open public spaces. In this way, the urban vision of Jacobs was confirmed on several occasions and the space syntax authors have come up with two very important conclusions: that it is necessary to study the space first, and then start with the design, and that the intensity of the network of pedestrian movements has the main role to its significance. In later research (80's of the $20^{\text {th }}$ century), Hillier identified types of street networks that support the life of open-air urban spaces experimentally (based on everyday experiences, behaviours, events, and especially between psycho-spatial quality, pedestrian movements, possible encounters, informal and formal social structures), in a world which enables us to understand the dynamics of open spaces. 


\subsection{Cultural Context as a Result of Morphological and Functional Characteristics}

Anthropologists believe that textual and collage metaphors were crucial in the creation of culture, and that the world was established by the principle of symbols, myths and rituals, which certain groups connect in appropriate circuits ideology (Ellin 1999; LeviStrauss 2001; Geertz 1964). Similarly, sociologist Suttles (1973) claims that communities were formed differently, because they were educated by different people, and that the task of the anthropologist was to decipher the messages they left recorded in the cities. This multifaceted space, with respect to multiculturalism and multi-ethnicity, is one of the foundations of modern thought in the field of urban design of open public spaces. Therefore, we can claim, that cultural heritage carries a spiritual message of its time and we cannot observe it outside the temporal and spatial framework. Open public spaces were formed in different periods of time, with different cultural and sociopolitical frameworks, from different social strata, in different ways. Different social groups were even excluded from public spaces in particular periods and cultures (in ancient Greece, free women were forbidden to walk freely in open public spaces, in New York in the $19^{\text {th }}$ century "women and children were subjected to short-term arrests if they were without male escort. The streets were perceived as a place of sexual danger." (Fyfe 1998). In the $19^{\text {th }}$ century, up to this day, the open public spaces were considered as a place of conflicts, and the streets were regarded as a place of sexual danger and scene for political events (public protests and political struggles). The cultural context implies socio-cultural characteristics of the ambience, and therefore the open public spaces are the parts of the city that its inhabitants are the most often identified with.

At the same time, open public spaces are the main city stage for the social events (Djukic 2011). Observed from the sociological aspect, the problem of the modern city is in the inability of its citizens to identify themselves with the environment in which they live, which affects the psycho-physical state of the individual. This problem is a consequence of citizens' dissatisfaction with the exaggerated insistence of architects and urbanists in a universal language or style in architecture, which negates historical experiences and local traditions. According to Baudrillard, the "aesthetics of break-in" was fashionable with previous patterns of fashion and social behaviour, while at the same time nurturing "the destruction of traditional forms". The discontent of the inhabitants caused by their inability to identify with certain urban areas (usually new residential areas) has sometimes culminated, leading to the alienation of individuals and various social deviations (suburbs of Paris, housing estates for social housing in England). Good architecture does not usually include good open spaces on which it is leaning, and good open public spaces, squares and streets can be framed with quite average architectural achievements.

Many authors refer to the "soul of the city", which is considered as a structural connection between the city and its inhabitants, and which as a historical category marks memory. Halbrouck pointed to the interaction between the city and its inhabitants, stressing the fact, that groups of people who have settled some space, adapt and 
change that space to their own ideas, but at the same time they adapt themselves to the space, closing within the boundaries they have formed (Djukic 2011). The picture of the external environment and the character of the relationship that the group has built up among each other, have a significant effect on the image that this group forms on itself. (Boyer 1995). Christina Boyer states that the unity between the past and the future is in the very idea of a city which permeates them, "as memory recalls the life of one person", and in order to realize the idea, it must shape reality, but it must also be shaped in its own way. These processes, which are recorded in individual urban units, monuments and our performances and the experiences of integrally possessing identities and continuity, explain in part the reasons for embedding bribes into the foundations of the city (Boyer 1995). According to Jung, the most important urban spaces and myths about them are inherited from our predecessors. We borrow them from the image of collective consciousness. And the Norbert-Schulz theorist emphasises familiarity, as a sense of belonging to some space, which is formed even in our childhood and which we carry in ourselves for the rest of our lives. It enables us to feel more comfortable in a certain area, to get better and to accept it as an integral part of our own memory image.

Physical forms are the product of cultural and social reflections on the one hand and individual aspirations of investors and architects on the other. However, open public spaces without users, activities and social contacts, are as scenes without actors and performances (Djukic 2011). The complexity of the relationship between the form and the open public space stems from the cultural and sociological patterns, but also from the inherited physical frames. It is difficult to determine what is older - the form or function, and what is necessary to start first, to activate the second.

\section{The Qualities of Open Public Spaces - Toward Liveable City}

Liveability is one of the key factors of the quality of the urban environment. Renowned Dutch architect, urban planner and humanist Jan Gehl, who was the creator of vital public spaces with human scale in cities like Copenhagen, New York and Melbourne, said: "Urban design is all about the human dimensions. Not about cars, industry or business. The quality of life has to be on the first place, followed up by space and buildings - other way round it does not work. If people perceive positively the city for their life, everything else will come gradually".

Walkability, as one of the factors of liveability, can be defined as a measure of how friendly an area or a city is. The idea of "walkable" neighbourhood conjures up a pre$19^{\text {th }}$ century, holistic view of health and well-being, combining notions of citizenship, civic life, democracy, resiliency, spiritual health, beauty, and social justice (Kashef 2016). The walkable neighbourhood has been associated with trust and social engagement (Leyden 2003) as well as sociability (Brown and Cropper 2001). Some people have negative perceptions on walking whether it's because they don't feel safe, or the pedestrian network is not adequate developed, absence of sidewalks, or because 
of climate comfort (usually thermal). One of the most important benefits of walking is improved quality of life. It could provide that city become a better place to live by helping people become healthier, encouraging social cohesion, decrease air pollution and provide people who do not drive a car an easy and safe walk to their destination.

At the very core of good urban design is a deep understanding of how residents live in the apartment block, district, neighbourhood, city and region. Quality of life is currently a new differentiator, cities compete in quality of life, providing its residents in habitability and liveability. Once the sufficient level to ensure the health, housing, employment, education, services and security is achieved, the quality of habitability is directly connected with the feelings of happiness and fulfilment of meaning of life. The most vulnerable part of the population must be taken into account, children, pensioners, economically, socially or physically disadvantaged. Liveable cities provide the full potential of possibilities and opportunities for people's lives and meaningful development of their families.

The concentration of pedestrians is one of the key factors for a successful walkable - neighbourhood and a city. According to many authors there is a strong connection between the experiences of urban space and presence of people using it (Gehl 2010; Jacobs 1995; Lynch 1974; Hiller and Henson 1984). It is related with the people's activities, cognitive experiences and also depends on the way people interact between each other. In that regard, Whyte considers that the number of the people in urban space is not the only important fact, it should include time they spend in the place, as well as the fact if they come alone or in groups (1980). Quality space and critical mass of users are prerequisites for processes in which small events can blossom (Jacobs 1995 ) and on the other hand, it is the main precondition for successful public space.

Walkability is defined by Abley and Turner (2011) as the degree that the urban environment is friendly to its users. According to Leslie et al. (2006) walkable is the place which, due to its characteristics, encourages people to walk. As Litman (1999) argues these characteristics are safety, convenience, comfort and the quality of pavements. For Hess and Farrow (2010) walkability is measured according to the attractiveness of pedestrians. Pivo and Fisher (2011) define the same parameter as the degree that inhabitants of an area are encouraged to reach by foot their close destinations. Walkability depends on the population density of an area, the mixite of land uses, the connectivity of the networks, the distance of principal destinations, the width of pavements, the distance between successive crossings, the topography of the urban landscape, the feeling of safety, the aesthetics of architecture etc. Walking and standing are the two sides of the same coin.

How to make our cities walkable is a crucial issue for Sustainable Urban Mobility Plans. These are the 21st century Combined Urban and Transport Plans which replace conventional planning. Their purpose is to reduce speeds and the number of cars in the streets, to enhance walking and cycling and to increase the role of public transport (Fig. 1). The vision for the city of tomorrow is to transform the streets in places to live and to socialize. This is a huge infrastructure and technological challenge (Vlastos 2014). 


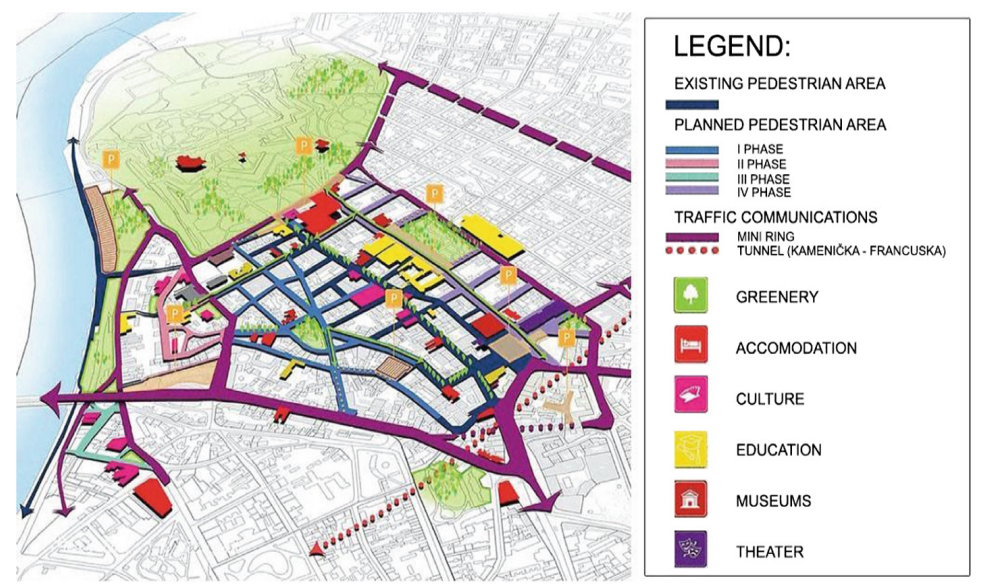

Fig. 1. Plan for widening the pedestrian network (car-free streets) within the historical center of Belgrade. Source: author Ana Delipara, in Folic M., Vukmirovic M (2016) "Projekat IME: Identity_Mobility_Environment of the City of Belgrade". City of Belgrade Communication Office, Belgrade.

\section{Future of Open Public Spaces or Are the Cyberparks for Cyborgs?}

What is the future of open public spaces? How they can become more vibrant and how they contribute to the liveability of a city? Although citizens in surveys which had been done in Belgrade during 2005 and 2016 have been concerned about the decrease of the quality of open public spaces, especially of the parks, the number of the open public space within the cities usually remains the same. Furthermore, some open public spaces are changing in a positive way, as it concerns technology. During the last three decades, ICT becomes the crucial part of our everyday life. ICT systems in cities, providing and ensuring low-cost internet access in open public spaces, are an indicator of development and the well-being of citizens (Djukic and Aleksic 2016). As Souza e Silva (2006: 262) has already pointed out, contemporary cities are 'hybrid spaces' where ICT, overlapping physical urban and information space, create hybrid space. People use social networks on everyday basis and interact in both the physical and virtual realms, gathering formally or informally in order to exchange information and knowledge, disseminate practice and experiences, and erase various kinds of limitations (Stupar and Djukic 2014). Citizens are also becoming interactive participants in the process of collaborative planning and design of the spaces they use. While the main role of an open public space is still to provide physical social contact between people a place where they can rest, recreate and enjoy the environment - e-networks have opened up additional channels of communication and diffusion and become a new tool for the continuous development of such locations (Stupar and Djukic 2014). Users acting as consumers of places can use ICT to participate as active contributors to the process of urban design or as critics of open urban space. 
'A cyborg is a cybernetic organism, a hybrid of machine and organism, a creature of social reality as well as a creature of fiction' (Haraway 1991: 149). Cyborgs use provided data and function according to them. Is the cyborg-flâneur a modern flâneur who adapts to a new technology? Mitchell introduced the cyber flâneur in 1996 in his writings 'I am an electronic flâneur. I hang out on the network ... The keyboard is my café' (p. 7). Cyborg flâneur explains how citizens use and inhabit the hybrid space. He is searching for pleasure and joy, while involving in activities associated with flaneur (games, virtual tours, online shopping, sharing social or Facebook status, virtual contacts with others) which allow the illusion of a certain freedom in hybrid space virtual reality.

\section{Conclusions and Future Developments}

The street has a history. Going out onto the street we leave behind us our private space and become part of the public and social sphere. Far from the protection of the private, we let go, we are open and free to communicate. We could easily avoid this by quickly getting into our car or a taxi. Instead, we are transported into a different world. Walking and cycling combine the personal and collective experience. The street is also an open public space where should be space for the citizens to stand and being present. Qualities of the street like accessibility, safety, comfort, attractiveness are crucial for liveability and social cohesion. Implementation of ICT's in open spaces and streets is crucial to enhance the above qualities. ICT's turn open spaces into digital places which are environments of socialization that compete with physical places. Technology is a new experience, and among other things, it is an urban game - playable city - which can transfer you anywhere, to any city. With augmented reality applications on the internet Cyborg-flaneur will live the city directly or indirectly, autonomously or collectively. He could even play with it. New communication technology will contribute greatly in this direction. Tomorrow's digital public city, a city of information, exchange, dialogue, meeting and playing will constitute a social field of liveliness and inspiration.

Cyberparks will become a new real and simultaneously digital world of places where the community will be connected with the local and the wider. In these places the live and digital exchange of information will be combined, and new social and political experiences will be acquired. The planet is becoming more unified, financially and culturally and is developing explosively under the umbrella of a new social digital public space of communication and exchange, which is the internet. In reality tomorrow, this will become our new home. Internet will be present everywhere, we will all share the same information and distance will count for nothing when it comes to exchange. As travellers on the web and citizens of the world we will know a lot about it since we will move intensively and therefore, we will be informed about everything that is happening. We will become more conscious about dangers the planet faces. The open public spaces of the city of tomorrow will be places for people prepared to discuss and find collective solutions. Cyborg-flaneur will be the citizen of tomorrow searching for pleasure and joy and solutions for surviving in our complex new world. 


\section{References}

Abley, S., Turner, S.: Predicting Walkability. NZ Transport Agency, Wellington (2011)

Alborg, C.: Charter of European cities \& towns towards sustainability (1994). http://ec.europa.eu/ environment/urban/pdf/aalborg_charter.pdf

Bentley, I., Alcock, A., Murrain, P., McGlynn, S., Smith, G.: Responsive Environments - A Manual For Designers. Butterworth Architecture, Oxford (1985)

Bridge, G., Watson, S.: A Companion to the City. Blackwell Companion to Geography, Oxford (2002)

Boyer, M.C.: The City of Collective Memory. The MIT Press, Massachusetts (1995)

Brown, B.B., Cropper, V.L.: New urban and standard suburban subdivisions: evaluating psychological and social goals. J. Am. Plan. Assoc. 67(4), 402-419 (2001)

CABE: The Value of Urban Design: A Research Project Commissioned by CABE and DETR. Thomas Telford, London (2001)

Crawford, M.: The world in a shopping mall. In: Sorkin, M. (ed.) Variations on a Theme Park: The New American City and The End of Public Space, pp. 3-30. Hill and Wang, New York (1992)

Cullen, G.: Townscape. Architectural Press, New York (1961)

De Souza e Silva, A.: From cyber to hybrid: mobile technologies as interfaces of hybrid spaces. Space Cult. 9(3), 261-278 (2006)

Djukic, A.: Keeping the Identity of the Main Streets in Vojvodina Towns in the Process of Urban Renewal (Doctoral dissertation, unpublished). Faculty of Architecture, Belgrade (2011)

Djukic, A., Aleksic, D.: Mixed reality environment and open public space design. In: Vanista Lazarevic, E., Vukmirovic, M., Krstic-Furundzic, A., Djukic, A. (eds.) International Academic Conference: Places and Technologies 2016: Keeping up with Technologies to Improve Places- Cognitive City, pp. 761-769 (2016)

Ellin, N.: Postmodern Urbanism. Princeton Architectural Press, New York (1999)

Fyfe, R.N.: Images of the Streets. Routledge, London and New York (1998)

Forty, A.: Words and Buildings. Thames \& Hudson, London (2004)

Gandl, S.: Glamur. CLIO, Belgrade (2007)

Gehl, J.: Cities for People. Island Press, Washington (2010)

Geertz, C.: Ideology as a cultural system. In: Ideology and Discontent, vol. 5 (1964)

Hall, A.C.: Design Control: Towards a New Approach. Butterworth Architecture, Oxford (1996)

Haraway, D.: Simians, Cyborgs and Women - The Reinvention of Nature. Free Association Books, London (1991)

Hess, P.M., Farrow, J.: Walkability in Toronto's High-Rise Neighbourhoods. University of Toronto, Toronto (2010)

Hiller, B., Henson, J.: The Social Logic of Space. Cambridge University Press, Cambridge (1984)

Jacobs, J.: The Death and Life of Great American Cities. Vintage Books, New York (1961)

Jacobs, A.: Great Streets. MIT Press, Massachusetts (1995)

Kashef, M.: Urban liveability across disciplinary and professional boundaries. Front. Arch. Res. 5(2), 239-253 (2016)

Kostof, S.: The City Shaped - Urban Patterns and Meanings Through History. Thames and Hudson, London (1973)

Kropf, K.: Urban tissue and the character of towns. Urban Des. Int. 1(3), 247-263 (1996)

Lash, S., Friedmann, J.: Modernity and Identity. Blackwell, Oxford (1992)

Lefebvre, H.: Writings on Cities. Blackwell, Oxford (1991) 
Leslie, E., Butterworth, I., Edwards, M.: Measuring the walkability of local communities using geographic information systems data. In: Walk 21-VII, Melbourne, Australia (2006)

Levi-Strauss, C.: Myth and Meaning. Routledge, London (2001)

Leyden, K.M.: Social capital and the built environment: the importance of walkable neighbourhoods. Am. J. Public Health 93(9), 1546-1551 (2003)

Litman, T.A.: Traffic calming benefits, costs and equity impacts. Victoria Transport Policy Institute, Victoria (1999)

Lynch, K.: Image of a City. The MIT Press, Massachusetts (1974)

Mitchell, W.J.: City of Bits: Space, Place and the Infobahn. MIT Press, Cambridge (1996)

Pivo, G., Fisher, J.D.: The walkability premium in commercial real estate investments. Real Estate Econ. 39(2), 185-219 (2011)

Rappaport, E.D.: Shopping for Pleasure: Woman and the Making of the London's West End. Princeton University Press, Princeton (2000)

Sennett, R.: The Fall of Public Man. Faber \& Faber, London (1974)

Stevens, Q.: The Ludic City: Exploring the Potential of Public Space. Routledge, New York (2007)

Stupar, A., Djukic, A.: Vis-à-vis communication? The digital and physical spaces of interaction in the contemporary city. In: Schrenk, M., Popovich, V., Zeile, P., Elisei, P. (eds.) International Scientific Conference "REAL CORP 2015 - Plan Together - Right Now Overall: From Visions to Reality for Vibrant Cities and Regions", pp. 687-693 (2014)

Suttles, G.: The Social Construction of Communities. University of Chicago Press, Chicago (1973)

Vlastos, T.: Les limites de la marche. Recherche - Transports - Securité, 30, 35-45 (2014)

Watson, S., Gibson, K. (eds.): Postmodern Cities and Spaces. Basil Blackwell, Oxford (1995)

Whyte, W.H.: The Social Life of Small Urban Spaces. Conservation Foundation, PPS, New York (1980)

Open Access This chapter is licensed under the terms of the Creative Commons Attribution 4.0 International License (http://creativecommons.org/licenses/by/4.0/), which permits use, sharing, adaptation, distribution and reproduction in any medium or format, as long as you give appropriate credit to the original author(s) and the source, provide a link to the Creative Commons license and indicate if changes were made.

The images or other third party material in this chapter are included in the chapter's Creative Commons license, unless indicated otherwise in a credit line to the material. If material is not included in the chapter's Creative Commons license and your intended use is not permitted by statutory regulation or exceeds the permitted use, you will need to obtain permission directly from the copyright holder.

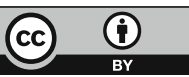

